\title{
NILAI - NILAI CINTA TANAH AIR DALAM PERSPEKTIF AL-QUR'AN
}

\author{
M. Alifudin Ikhsan \\ Program Studi Magister Pendidikan Pancasila dan Kewarganegaraan Universitas Negeri Malang \\ Jl. Semarang No.5 Malang \\ email: um.alifudin93@gmail.com
}

\begin{abstract}
Nasionalism is a feeling of pride and participate in having a certain territory. This feeling is manifested in a willingness to sacrifice to protect its territory from a variety of threats and threats. The importance of the love of this homeland makes it a natural human nature that has been born. However, the problematic nowadays is the specialization of the meaning of love the homeland in everyday life. The dichotomy of the rejection of the Ashobiyah Islamist movement towards the nation state is one of the proofs of narrowing the meaning of love of the homeland in society. The study of this subject reveals the concept or idea related to love of the homeland in terms of religion and nation. This is important to do in order to create a more contextual understanding of the phenomenon of understanding the problem of love homeland. This study is very important to do given the lack of deep study of exploration of the content of the Qur'an in solving social problems that occur today. His hope with the study of this topic can open the public insight about the concept of love homeland in the Qur'an. This research reveals the values of love of the homeland in the perspective of the Qur'an
\end{abstract}

Key Words : values, nasionalism, Qur'an

\begin{abstract}
Abstrak: Cinta tanah air (hubb al wathan) merupakan perasaan bangga dan ikut memiliki sebuah wilayah tertentu. Perasaan ini diwujudkan dalam sikap rela berkorban untuk melindungi wilayahnya dari berbagai ganggungan dan ancaman. Pentingnya rasa cinta tanah air ini menjadikannya sebuah tabiat alamiah manusia yang dimiliki sejak lahir. Namun, yang menjadi problematika saat ini adalah spesialisasi makna cinta tanah air dalam kehidupan sehari-hari. Dikotomi penolakan gerakan Islam Ashobiyah terhadap paham negara bangsa (nation state) menjadi salah satu bukti penyempitan makna cinta tanah air di masyarakat. Kajian terhadap pokok bahasan ini mengungkapkan konsep atau gagasan terkait cinta tanah air yang ditinjau dari segi agama dan bangsa. Hal ini penting untuk dilakukan agar tercipta pemahaman yang lebih kontekstual terhadap fenomena problematika paham cinta tanah air. Penelitian ini sangat penting untuk dilakukan mengingat sedikitnya kajian yang mendalam terhadap eksplorasi kandungan Alquran dalam memecahkan problematika sosial yang terjadi saat ini.Harapannya dengan dikajinya topik ini dapat membuka wawasan masyarakat tentang konsep cinta tanah air dalam Alquran. Penelitian ini mengungkap nilai-nilai cinta tanah air dalam perspektif Alquran.
\end{abstract}

Kata Kunci: nilai, cinta tanah air, Al-Qur'an

Nasionalisme adalah konsep modern yang muncul pada abad ke-17 bersamaan dengan lahirnya konsep negara bangsa. Di Eropa, nasionalisme muncul sebagai salah satu perwujudan perlawanan terhadap feodalisme (kekuasaan absolut yang dimiliki oleh pemuka agama dan bangsawan). Seiring munculnya negara bangsa, timbullah berbagai pemikiran tentang nasionalisme sebagai basis filosofis terbentuknya negara bangsa tersebut. Jamaluddin (2015:16) mengatakan bahwa suatu bangsa terbentuk karena adanya unsur-unsur dan akar-akar sejarah yang membentuknya. Oleh karena itu, dibutuhkan pemikiran bahwa pengabdian tertinggi seorang manusia untuk bangsa dan negara disebut dengan nasionalisme.

Setidaknya terdapat beberapa konsep persatuan atau persaudaraan dalam Islam yang 
dikenal dengan istilah ukhuwah (persaudaraan) yaitu ukhuwah Islamiyah (persaudaraan umat Islam), ukhuwah wathaniyyah (persaudaraan bangsa) dan ukhuwah basyariyah (persaudaraan umat manusia). Pada penelitian ini, penulis ingin menegaskan tentang pentingnya ukhuwah wathaniyah dan ukhuwah basyariyah. Penulis berpandangan, ukhuwah wathaniyah (persaudaraan bangsa) ini harus didahulukan dan diutamakan karena tanpa negara umat Islam tidak akan bisa menjalankan kegiatan ibadahnya. Dalam kaitannya dengan hal ini, nasionalisme atau cinta tanah air dibangun berdasarkan nilai-nilai luhur yang telah ada di dalam diri setiap manusia.

Sebagai paham atau ajaran yang muncul dari Barat (Eropa), nasionalisme dimaknai beragam oleh berbagai golongan Islam di tanah air. Konsep cinta tanah air yang sejatinya berada pada tataran ruh jasmaniyah setiap insan, harus diterjemahkan ke dalam berbagai pemikiran terkait hubungan cinta tanah air dan Islam. Siroj (2015:6) mengatakan bahwa Islam dan negara adalah hal yang tidak bisa dipisahkan. Pemaknaan masyarakat tentang konsep negara dan agama terus menjadi persoalan yang masif di kalangan akademisi, ulama' dan pemimpin negara (Jamaluddin, 2015:17). Salah satu pemaknaan yang dilontarkan adalah apakah cinta tanah air diperintahkan dalam Alquran?.

Melihat hal tersebut, masyarakat golongan Ashobiyyah dengan tegas berpendapat bahwa cinta tanah air hukumnya haram dilakukan oleh umat Islam. Hal ini dikarenakan tidak ada satupun nash Alquran dan hadis nabi yang memerintahkan mencintai negaranya atau tanah airnya. Di sisi yang lain, umat Islam juga dihadapkan dengan pendapat bahwa mencintai tanah air merupakan bagian dari bentuk syukur atas penciptaan makhluk Allah. Pada hakikatnya, golongan ini berpendapat bahwa mencintai tanah air adalah mencintai Allah. Dari dikotomi perbedaan pandangan inilah, penelitian ini hadir untuk memberikan wawasan baru dalam kaitannya dengan cinta tanah air dalam perspektif Alquran.

Alquran sebagai kitab suci umat Islam memang tidak menjelaskan secara langsung (tekstual) pentingnya rasa cinta tanah air ( $h u b b$ al-wathan), tetapi nilai-nilai yang terkandung di dalamnya mampu menjawab segala macam pertanyaan tentang pentingnya cinta tanah air (Wahid, 2015:20). Di antara nilai-nilai tersebut adalah semangat persatuan dan kesatuan (ukhuwah wathaniyah) serta tuntunan untuk selalu menghormati dan menghargai sesama manusia. Alquran telah menerangkan bagaimana sikap manusia terhadap negara. Namun, problematika kontemporer di abad ke-21 ini adalah mengikisnya rasa cinta tanah air warga negara. Diakui atau tidak, sikap penolakan terhadap adanya konsep negara bangsa masih sering terdengar di masyarakat. Penelitian ini menegaskan konsep atau gagasan cinta tanah air dalam Alquran yang dikuatkan dengan kajian sumber hukum Islam. Lainnya. Harapannya, dikajinya topik ini dapat membuka wawasan masyarakat tentang nilai-nilai cinta tanah air dalam Alquran. Oleh karena urgensi tersebut, penulis ingin mengkaji "Nilai-Nilai Cinta Tanah Air (Hubb Al-Wathan) dalam Prespektif Al-Qur'an".

\section{METODE}

Kajian ini menggunakan pendekatan kepustakaan (library research). Penelitian ini berorientasi pada pengumpulan data-data yang terdapat dalam berbagai sumber baca yang ada.Berbagai bahan pustaka dan data informasi yang digunakan berasal dari berbagai buku, jurnal ilmiah, media massa baik cetak maupun elektronik, data pemerintah, artikel dan sumber-sumber bacaan lainnya. Jenis penelitian ini juga merupakan salah satu penelitian yang berfokus pada pengembangan teori atau pencarian solusi atas permasalahan yang bersifat gagasan.

Menurut Zed (2014:4-5) setidaknya terdapat empat ciri utama penelitian kepustakaan. Pertama peneliti berhadapan langsung dengan teks (nash) atau data angka yang bukan berdasarkan pengetahuan langsung di lapangan. Kedua, data pustakan bersifat tetap atau siap pakai. Ketiga, kepustakaan adalah sumber atau data sekunder dalam arti peneliti memperolehnya dari pihak kedua. Keempat, kondisi data pustaka tidak dibatasi oleh ruang dan waktu. Penelitian ini juga menggunakan telaah studi naskah. Yakni penelitian terhadap teks-teks Alquran yang membicarakan tentang suatu masalah tertentu.

Teknik pengumpulan data yang digunakan dalam penelitian ini merupakan teknik penelitian dengan menggunakan metode dokumentasi. Metode dokumentasi ini merupakan salah satu kegiatan untuk mencari suatu data mengenai beberapa hal yang dapat berupa catatan, buku, artikel, media massa, dan beberapa sumber bacaan 
lainnya yang dapat diterima kebenarannya berdasarkan kajian ilmiah yang ada. Berdasarkan penggunaan acuan di atas, peneliti dapat menggunakan dua model penelaahan atau analisis terhadap kajian yang dilakukan. Analisis deduktif dilakukan berdasarkan teori-teori atau konsepkonsep umum yang ada dan relevan serta analisis induktif yang dilakukan berdasarkan sintesis penelitian sebelumnya. Dari konteks inilah, penelitian ini dikembangkan untuk mengkaji nilainilai cinta tanah air dalam perspektif Alquran.

\section{HASIL DAN PEMBAHASAN}

\section{Konsep Dasar Cinta Tanah Air}

Menurut Al-Buthy (2010:vii) "Cinta dapat diartikan ke dalam tiga karakteristik yaitu apresiatif (ta'dzim), penuh perhatian (ihtimaman) dan cinta (mahabbah). Secara spesifik, bahasa Arab menyebutnya dengan 60 istilah cinta seperti 'isyqun (menjadi asyik), hilm, gharam (asmara), wajd, syauq dan lahf. Namun Alquran hanya menyebut 6 terminologi ini"'.Berdasarkan pandangan Al Buthy di atas dapat penulis simpulkan bahwa cinta yang dimaksud disini adalah perasaan kasih, perhatian dan kepedulian yang ditujukan kepada seseorang untuk tanah airnya. Perasaan cinta tersebut dapat membangkitkan dirinya untuk rela mengorbankan jiwa dan raganya dalam mengemban tugas negara dan untuk mempertahankan tanah airnya. Dalam ilmu Psikologi, perasaan cinta sebenarnya mengandung unsur kasih dan sayang terhadap sesuatu. Kemudian di dalam diri seseorang tersebut akan tumbuh kemauan untuk merawat, melindungi dan memeliharaya dari segala ancaman yang timbul (Kamilin, 2014:24).

Ada beberapa istilah yang mempunyai makna tanah air diantaranya yaitu $A l$-Wathan, Al-Balad dan Dar. Dalam kamus Mu'jam al-Wasith (2011:1085) disebutkan bahwa Al-Wathan berarti tempat tinggal seseorang, tempat dimana ia bertumbuh dan tempat dimana ia dilahirkan.AlBalad mempunyai arti tempat yang dibatasi yang dijadikan tempat tinggal oleh sekelompok orang, atau dinamakan dengan tempat yang luas yang ada di bumi ini.

$$
\text { الدار هو المحل يجمع البناء والساحة والمنزل }
$$

Sedangkan dar berarti tempat berkumpulnya bangunan dan halaman, tempat tinggal. Ketiga kata tersebut mempunyai makna yaitu tempat tinggal. Dalam kitab asas al-balaghah karya AzZamarkashi menyatakan bahwa cinta tanah air yakni masing-masing orang mencitai tanah airnya, negeri asalnya dan tempat tinggalnya. (Imarah, 1998:271).

Menurut Kamus Besar Bahasa Indonesia (Depdikbud, 2002:778) cinta tanah air adalah perasaan yang timbul dari hati sanubari seorang warga negara untuk mengabdi, memelihara, membela, melindungi tanah airnya dari segala ancaman dan gangguan. Cinta tanah air berarti membela dari segala macam gangguan dan ancaman yang datang dari manapun. Cinta tanah air merupakan rasa kebanggaan, rasa memiliki, rasa menghargai, rasa menghormati dan loyalitas yang tinggi yang dimiliki oleh setiap individu pada negara tempat ia tinggal yang dapat tercermin dari perilaku membela tanah airnya, menjaga dan melindungi tanah airnya, rela berkorban untuk kepentingan bangsa dan negaranya serta mencintai adat dan budaya yang dimiliki oleh bangsanya (Nurmantyo, 2016:9). Menurut Suyadi sebagaimana dikutip oleh Kemendikbud (2013:9) cinta tanah air adalah sikap dan perilaku yang mencerminkan rasa bangga, setia, peduli dan penghargaan yang tinggi terhadap bahasa, budaya, politik dan sebagainya sehingga tidak mudah menerima tawaran bangsa lain yang dapat merugikan bangsa sendiri.

Cinta tanah air hendaknya dipahami secara luas dan dimengerti maksud serta tujuannya. Cinta tanah air juga sering dikenal dengan istilah nasionalisme. Secara ringkas nasionalisme merupakan paham kebangsaan yang merupakan kesetiaan tertinggi individu terhadap bangsa dan tanah airnya. Cinta tanah air pada hakikatnya merupakan bagian yang tak terpisahkan dalam diri setiap manusia. Sebagaimana pengertian cinta tanah air di bagian sebelumnya, cinta tanah air identik dengan sebutan nasionalisme. Nasionalisme menurut Kamus Besar Bahasa Indonesia berarti suatu paham yang berpendapat bahwa kesetiaan tertinggi individu yang harus diserahkan kepada negara kebangsaan (Depdikbud, 2003).

Faktor pembentuk identitas bersama menurut Ramlan Surbakti (1999:44-47): (1) Primordial, yaitu ikatan kekerabatan dan kesamaan suku bangsa, daerah, bahasa, dan adat istiadat untuk membentuk suatu negara atau bangsa. Primordial ini tidak hanya menimbulkan pola perilaku yang sama tetapi juga melahirkan persepsi tentang 
negara yang dicita-citakan. (2) Sakral, yakni kesamaan agama yang dipeluk oleh suatu masyarakat. Faktor sakral ini ikut menyumbangkan terbentuknya sifat nasionalis dalam diri individu di dalam suatu negara. (3) Tokoh, kepemimpinan dalam suatu komunitas dapat menjadi salah satu faktor yang membentuk suatu negara atau bangsa. Sebab, pemimpin ini akan menjadi panutan masyarakat sebagai simbol persatuan dan kesatuan untuk membentuk komunitas baru yang lebih besar (4) Sejarah, Persepsi yang sama tentang asalusul atau pengalaman masa lalu seperti kejayaan dan penderitaan juga dapat membentuk solidaritas yang tinggi (Surbakti, 1999:44-45).

Sejarah juga akan dapat menimbulkan tekad dan tujuan yang kuat dalam suatu masyarakat. (5) Bhinneka Tunggal Ika, prinsip bersatu dalam perbedaan (unity in diversity) dapat menjadi faktor pembentuk identitas bersama. Hal ini dikarenakan kesetiaan masyarakat terhadap suatu bangsa atau negara dipandang perlu meninggalkan unsur perbedaan diantara mereka. Hal ini akan menimbulkan kesetiaan yang ganda dalam diri masyarakat. (6) Perkembangan Ekonomi, Perkembangan ekonomi (industrialisasi) akan melahirkan spesialisasi pekerjaan yang beraneka ragam sesuai dengan kebutuhan masyarakat. Solidaritas yang ditimbulkan dari situasi ini disebut dengan solidaritas organis. (7) Kelembagaan, Faktor lain yang menjadi pembentuk solidaritas kebangsaan adalah terbentuknya kelembagaan seperti lembaga-lembaga politik pemerintahan, birokrasi angkatan bersenjata dan berbagai lembaga lainnya yang dapat membantu mewujudkan suasana sejahtera dalam suatu negara (Surbakti, 1999:46-47).

\section{Cinta Tanah Air (Hubb Al Wathan) dalam Perspektif Al-Qur'an}

Pada awalnya, Islam tidak mengenal istilah nasionalisme. Adapun yang dikenal hanya dua konsep teritorial-religious yakni wilayah damai (Darul Islam) dan wilayah perang (Darul Harb). Oleh karena itu, munculnya konsep negara bangsa (nation state) telah melahirkan beberapa ketegangan historis dan konseptual dikalangan Islam. Meski demikian, di dalam Islam dikenal dua terminologi yang mendekati konsep negara-bangsa yaitu kata millah dan ummah yang berarti masyarakat atau umat. Akan tetapi istilah tersebut lebih mengacu pada kelompok sosio-religius bukan kepada masyarakat politik. Pada pihak lain, konsep negara-bangsa mengacu atas kriteria etnisitas, kultur, bahasa dan wilayah serta mengabaikan unsur religius. Sedangkan pada tataran institusional konsep negara-bangsa berbenturan dengan konsep khilafah atau panislamisme (Azra, 1996:12).

Nasionalisme di dunia Islam dapat dipelajari dari sejarah negara-negara muslim yang ada di dunia yang bersentuhan secara langsung dengan masyarakat dan negara-negara eropa. Turki adalah salah satu negara muslim yang menerima secara terbuka konsep nasionalisme sebagaimana yang ada di negara-negara barat. Disnasti Turki Utsmani kala itu menguasai hampir seluruh kawasan Timur Tengah. Negara-negara ini mengakui dan mengagumi beberapa konsep politik eropa diantaranya di bidang adminitrasi negara dan militernya (Azra, 1996:46)

Pada dasarnya, kata cinta tanah air dalam Alquran tidak disebutkan secara langsung. Namun nilai-nilai kandungan Alquran banyak ditemukan dalamAlquran. Berbagai nilai cinta tanah air dalam prespektif Alquran diantaranya sikap nasionalisme dan rela berkorban. Cinta tanah air menjadi salah satu bagian dari nilai-nilai Alquran yang luhur. Sebagaimana telah dicontohkan oleh para nabi dan rasul yang telah memberikan isyarat berbagai fenomena dan peristiwa yang terjadi sebagai pelajaran berharga dalam menghadapi setiap perubahan masa.

\section{Kajian Cinta Tanah Air dalam Q.S. Al Hujurat Ayat 13}

Alquran merupakan kitab suci ummat Islam yang diimani dan dipercayai. Alquran tidak menjelaskan secara pasti tentang pentingnya rasa cinta tanah air (hubb al-Wathan) tetapi nilai-nilai yang terkandung di dalamnya mampu menjawab segala macam pertanyaan tentang pentingnya cinta tanah air. Diantara nilai-nilai tersebut adalah semangat persatuan dan kesatuan (Ukhuwah Islamiyyah) serta tuntunan untuk selalu menghormati dan menghargai sesama manusia. Inilah salah satu nilai dari cinta tanah air yang ada dalam Alquran, tentu saja nilai tersebut bukanlah satu-satunya nilai yang mencerminkan cinta tanah air melainkan masih banyak nilai-nilai yang terkandung di dalam firman Allah ini.

Berikut merupakan kajian Alquran Surat AlHujurat ayat 13 yang menjelaskan tentang konsep cinta tanah air dalam prespektif Islam. 
Artinya: Hai manusia, Sesungguhnya Kami menciptakan kamu dari seorang laki-laki dan seorang perempuan dan menjadikan kamu berbangsa -bangsa dan bersuku-suku supaya kamu saling kenalmengenal. Sesungguhnya orang yang paling mulia diantara kamu disisi Allah ialah orang yang paling taqwa diantara kamu. Sesungguhnya Allah Maha mengetahui lagi Maha Mengenal (Kemenag, 2016:447)

Sebab turunnya ayat ini yaitu Ibnu Abi Hatim meriwayatkan dari Abi Malakah yang berkata, "Setelah pembebasan kotaMekah, Bilal naik ke atas ka'bah lalu mengumandangkan adzan" (al Naisabury, 2009:264). Melihat hal itu, sebagian orang lalu berkata, "Bagaimana mungkin budak hitam iniyang justru mengumandangkan adzan di atas ka'bah!" sebagian yang lain berkata dengan nada mengejek, "Apakah Allah akan murka kalau bukan dia yang mengumandangkan adzan? Kemudian Allah menurunkan ayat ini (asy-Suyuthi, 2010:107).

Ibnu Asakir meriwayatkan dalam kitab alMubhamaat, ayat ini turun berkenaan dengan Abi Hindun, suatu ketika Rasulullah menyuruh Bani Bayadhah untuk menikahkan Abu Hindun ini dengan wanita dari suku mereka (Shaleh, 2003:457). Akan tetapi, mereka berkata, "wahai Rasulullah, bagaimana mungkin kami akan menikahkan anak wanita kami dengan seorang budak". Kemudian turunlah ayat ini (asy-Suyuthi, 2011:530). Menurut Al Imam Abul Fida Isma'il (Ibnu, 2009:348) Q.S. Al Hujurat ayat 13 ini menegaskan kesatuan asal-usul manusia dengan menunjukkan kesamaan derajat kemanusiaan.

Apabila diperhatikan struktur bahasa ayat di atas memuat beberapa makna berikut, kata (ياريها) merupakan huruf nida' yang berarti seruan atau panggilan kepada manusia. Jika kata (يايها) merupakan huruf nida' maka kata (الناس) merupakan munada' yang berarti manusia. Inna (ن) merupakan huruf taukid yang berfungsi menashabkan isimnya dan merafa'kan khabarnya. Dzamirmuttasil nahnu merupakan isim (نا) dalam kondisi nashab karena menjadi isimnya. Kalimat khalaqnakum (خلقناكم) pada ayat di atas berkedudukan sebagai rafa' karena menjadi khabar (نا). Sedangkan kata khalaqa merupakan fiil madhi,dzamir muttasil na dalam kondisi rafa' karena menjadi fail. Sedangkan dzamir muttasil kum (كم) dalam kondisi nashab karena menjadi maf'ul bih.

Kalimat من ذكر وانثى dapat dimaknai sebagai sebagian laki-laki dan perempuan. Kata min من adalah huruf jer dengan harakat tetap selamanya yakni sukun. Kata ذكر adalah isim majrur karena ada huruf jer, selain itu kata tersebut juga berkedudukan sebagai ma'tuf alaih. Sedangkan mempunyai arti perempuan atau wanita yang menjadi isim dalam kondisi jer karena berposisi sebagai ma'tuf.Rangkaian kalimat yang berarti sesungguhnya benar-benar telah kami ciptakan kalian dari golongan laki-laki dan perempuan merupakan ma'tuf alaih. Kalimat وجعاك mempunyai arti telah menjadikan kalian. Kata kalian di sini dimaksudkan pada kalimat من ذكر و yaitu laki-

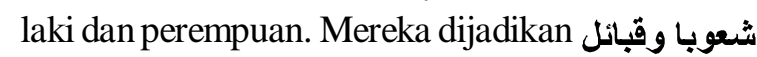
berbangsa-bangsa dan bersuku-suku agar mereka saling mengenal dan mengetahui satu sama lainnya.

Dalam Tafsir Al-Misbah (Shihab, 2014:445) mengatakan bahwa ayat di atas dapat dimaknai sebagai salah satu wujud penisbatan manusia terhadap tanah kelahirannya atau tanah air. Itu artinya mereka telah memiliki rasa cinta terhadap tanah tumpah darahnya sejak lahir dan hal itu merupakan bentuk kodrati. Senada dengan hal tersebut, dalam kitab Ar-Risalah karya Hadratussyeckh Hasyim Asy'ari menerangkan bahwa membela negara yang sedang mengalami penjajahan adalah hal yang wajib. Dari pendapat inilah kemudian dikenal istilah $\mathrm{Hubb} \mathrm{Al}$-Wathan Minal Iman yang dipopulerkan oleh KH. Wahab Hasbullah. Lebih lanjut dalam memaknai kajian Alquran surat Al-Hujurat di atas, di kalangan umat Islam Indonesia, nasionalisme dimasuki ruh-ruh nilai-nilai Islam. Masyarakat muslim yang melaksanakan agamanya dengan benar akan memiliki rasa nasionalisme (Jamaluddin, 2015:18).

\section{Kajian Ijtihad Ulama' 'Hubb Al Wathan Minal Iman"}

Para ulama' Indonesia mengeluarkan pendapat tentang cinta tanah air bagi seluruh warga negara. Dalam putusan Majelis Ulama' Indonesia (MUI), membela tanah air adalah wajib. Ungkapan yang paling populer dikalangan bangsa Indonesia adalah pendapat ulama' yang mengungkapkan kalimat: Cinta tanah air adalah bagian 
dari iman.Jika dilihat dari makna katanya, kalimat "Hubb" mempunyai arti cinta atau senang atau rasa memiliki. "Al Wathan" dapat diartikan sebagai tanah air atau tanah tumpah darah atau tanah kelahiran. "Min" merupakan huruf jer yang dapat diartikan sebagai atau sebagian dari. Kata "Al Iman" berarti kepercayaan atau ketauhidan, Iman juga berarti perasaan percaya tertinggi manusia kepada tuhannya. Sedangkan apabila dilihat menjadi satu kesatuan kalimat, maka " $\mathrm{Hubb}$ Al Wathan Minal Iman" dapat berarti cinta tanah air adalah sebagian dari iman (Jamaluddin, 2015:16).

Ijtihad ulama' tersebut tidak terlepas dari fatwa resolusi jihad NU yang dikeluarkan oleh KH. Hasyim Asy'ari pada tahun 1945. Makna resolusi jihad tersebut berarti kewajiban setiap umat Islam untuk berjuang membela negara dan bangsa Indonesia dalam menghadapi penjajahan Belanda dan Jepang. Resolusi jihad tersebut menjadi salah satu penyulut semangat rakyat Indonesia dalam perang 10 Nopember 1945 di Surabaya yang merupakan perlawanan terbesar bangsa Indonesia setelah Proklamasi Kemerdekaan Republik Indonesia.

Sebagai salah satu ulama' yang berpengaruh di Indonesia, KH. Hasyim Asy'ari menyerukan perlawanan dan perjuangan terhadap penjajah. Makna yang terkandung dalam bait " $\mathrm{Hubb} \mathrm{Al}$ Wathan" adalah sebuah penghambaan manusia terhadap tuhannya. Hal ini bukan berarti menjadikan tanah air sebagai tuhan atau sesembahan, melainkan mewujudkan perasaan cinta kepada Allah. Cinta terhadap Tuhan adalah suatu kewajiban seorang manusia. penghambaan manusia kepada tuhannya dapat ditandai dengan mencintai makhluk ciptaanNya. Salah satunya dengan mencintai tanah airya sebagai ungkapan syukur atas karunia Tuhan yang telah memberikan segala karunianya. Jika dicermati lebih dalam, makna kalimat "Hubb Al Wathan" adalah cinta tanah air sebagai wujud syukur terhadap melimpahnya karunia Tuhan terhadap tanah airnya. Hal ini juga sesuai dengan Maqasid Asy Syari'ah diantaranya menjaga agama, nyawa, harta benda, keturunan dan tanah airnya.

\section{DAFTAR RUJUKAN}

Al Naisabury, A. H.., 2009. Asbab Al-Nuzul AlQuran.Beirut: Dar Al-Fikr.

As-Syiddiqie, H. M., 1971.Tafsir Al-Bayan. Bandung: Aksara.

\section{SIMPULAN}

1. Perasaan cinta tanah air dapat diwujudkan setidaknya dengan (1) menjaga nama baik bangsa; (2) berjiwa dan berkpribadian; (3) bangga bertanah air dengan beragam suku budayanya; (4) tidak melakukan perbuatan dan tindakan yang merugikan bangsa serta (5) setia dan taat pada aturan dan norma yang berlaku. Persamaan nasib dan kondisi serta letak geografis yang sama membuat masyarakat Indonesia memiliki ikatan persatuan yang kuat. Dari kondisi ini, dapat penulis simpulkan bahwa konsep cinta tanah air Indonesia dibangun berdasarkan sejarah panjang, kesamaan nasib, letak geografis, kondisi psikologis dan tujuan serta cita-cita yang sama yang membuat masyarakat Indonesia memiliki rasa nasionalisme yang tingg

2. Kata cinta tanah air secara implisit terdapat dalam Alquran. Nilai-nilai cinta tanah air dalam prespektif Alquran di antaranya sikap nasionalisme dan rela berkorban. Cinta tanah air menjadi salah satu bagian dari nilai-nilai Alquran yang luhur. Sebagaimana telah dicontohkan oleh para nabi dan rasul yang telah memberikan isyarat berbagai fenomena dan peristiwa yang terjadi sebagai pelajaran berharga dalam menghadapi setiap perubahan masa. Konsep cinta tanah air dalam Alquran, hadis dan ijtihad para ulama' merupakan universal values dari cinta tanah air.

3. Beberapa nilai cinta tanah air yang terdapatdalam Alquranadalah: (1) nilai persatuan dan kesatuan, terdapat dalam Q.S. Al Anbiya':92, Q.S. Al Hujurat:13, Q.S. Ali Imron:103, dan Q.S.As Shaff:4 (2) nilai rela berkorban, terdapat dalam Q.S. Al Anfal:60, Q.S. Qashsas:7, dan Q.S. An Nisa':135 (3) nilai kesetiaan, terdapat dalam Q.S. An Nisa':59, dan Q.S. Ali Imron:103 (4) nilai taat terhadap peraturan perundangundangan, terdapat dalam Q.S. An Nisa':59, dan Q.S. An Nisa': 135 (5) nilai toleransi antarumat beragama terdapat dalam Q.S. Al Mumtahanah:8, dan Q.S. Al An'am:108,. Beberapa nilai tersebut juga memiliki kaitan dan dasar hukum dalam Alquran dan hadis.

Asy-Suyuthi, J. A. b. A. B., 2010. Ad-Durrul Mantsur Fi At-Tafsiir Ma'tsur. Beirut: Dar Al-Kutb Al-Ilmiyah.. 
Dault, A., 2005. Islam dan Nasionalisme: Reposisi Wacana Universal dalam Konteks Nasional.Jakarta: Pustaka AlKautsar.

Depdikbud, RI., 2002. Kamus Besar Bahasa Indonesia. Jakarta: Departemen Pendidikan dan Kebudayaan.

Jamaluddin, M., 2015. Nasionalisme Islam Nusantara: Nasionalisme Santri. Jakarta: Kompas Media Pustaka.

Kamilin, A. D., 2014. Cinta dalam Pandangan Penghafal Alquran. Malang: Fakultas Pendidikan Psikologi Universitas Negeri Malang.

Kemenag, RI. Al-Qur'an dan Terjemahnya. Jakarta: Kementerian Agama Republik Indonesia.

Nurmantyo, G., 2016. Memahami Ancaman, Menyadari Jati Diri sebagai Modal
Membangun Menuju Indonesia Emas.Jakarta: Litbang. Tentara Nasional Indonesia.

Shaleh, Q., 2003. Asbabun Nuzul Latar Belakang Historis Turunnya Ayat-ayat Alquran.Bandung: Diponegoro Press.

Shihab, Q., 2014. Tafsir Al-Misbah: Pesan, Kesan dan Keserasian Al-Quran. Jakarta: Lentera Hati.

Siroj, S. A., 2015. Nasionalisme Islam Nusantara: Mendahulukan Cinta Tanah

Surbakti, R. 1999. Memahami Ilmu Politik. Jakarta: Grasindo.

Wahid, S., 2015. Nasionalisme Islam Nsantara: Keindonesiaan dan Keislaman. Jakarta: Kompas Media.

Zed, M., 2014. Metode Penelitian Kepustakaan. Jakarta: Yayasan Obor Pustaka Indonesia. 